\title{
Petit Granit: A Belgian limestone used in heritage, construction and sculpture
}

\author{
1 Dept. of Geology, Plaza de la Merced s/n, University of Salamanca, 37008 Salamanca, Spain. E-mail: mdp@usal.es \\ 2 "Pierres et Marbres de Wallonie" ASBL, Rue des Pieds d'Alouette, 11, B-5100 Naninne, Belgium. E-mail: francis.tourneur@ \\ pierresetmarbres.be \\ 3 La Soledad 7, 4C, 37001 Salamanca, Spain.E-mail: lorenzo.bernaldez.villarroel@gmail.com
}

(Received September 7, 2014; Revised accepted October 01, 2014)

\section{Petit Granit is a Carboniferous grey-bluish crinoidal} limestone that becomes shiny black when polished. The rock is known under several other names including Pierre bleue (Blue stone), but it should not be confused with other natural stones having a similar commercial name, which are superficially similar limestones. It consists of around $96 \%$ microcrystalline calcite and a high proportion of fossils, mainly crinoids. In addition some dolomite, quartz, pyrite, marcasite and fluorite are present. Around fifteen quarries are currently active, employing almost one thousand people and thus is an important part of the natural stone economy in Belgium. Petit Granit has an Appellation d'Origine Locale (Local Appellation of Origin) designation since 1999. It has been extracted in several regions of southern Belgium since the Middle Ages.

The stone characterizes many façades of the urban architecture of Brussels and other Belgian cities, and since the second half of the $19^{\text {th }}$ century it has been used in various countries elsewhere in Europe and overseas. Its high density and uniformity mean that it takes an excellent polish and thus has versatile use as a dimension stone. Petit Granit has also been used widely in sculpture and architecture by several well known artists. However, deterioration has been observed when it has been used for exterior purposes, and appropriate measures need to be taken to prevent this. This stone can be considered as a possible candidate for Global Heritage Stone Resource nomination in Europe for its prominence and value both in construction and artistic uses.

\section{An introduction to "Petit Granit"}

Petit Granit is a calcareous grey-blue stone, giving rise to the local name "Pierre Bleue," characterized by an abundance of crinoids. With polishing, this stone becomes dark, but when used in exteriors, it loses its polish in a relatively short period of two to three years and becomes significantly lighter and greyer in colour. Its extraction is exclusively from Belgium, in the area around Soignies in the Hainaut province and around the Ourthe valley and in Condroz, as in the Bocq and Molignée valleys (Figure 1). The rock is Early Carboniferous in age (Tourneur, 2004; Groessens and Tourneur, 2011; Groessens, 2013) and comprises the Soignies Member of the Écaussinnes Formation. A variety exists in some of the older strata, of middle Tournaisian age, named "Petit Granit du Bocq", after the Bocq valley, a tributary of the Meuse river, to the east of the municipality of Yvoir, where it is still exploited.

The name of the stone, Petit Granit, is somewhat misleading, as it applies a term for an igneous rock to a sedimentary rock. However, the fact that this limestone encloses numerous fossil fragments of white crinoids, brachiopods and locally corals, which look superficially like feldspars in granites (Figure 2). This needs to be pointed out because a number of sculptures in museums and catalogues made with this limestone are labelled as "Black Granite", with the consequent misinformation for visitors (e.g. Hernández, 1950; Sotheby's catalogue, 2008, 2011; Museo Mateo Hernández, Béjar, Salamanca)

On freshly broken surfaces, the cleavage planes of the crinoid fragments are reflective, giving a coarse-grained appearance. The name Petit Granit is relatively old, used at least since the end of $18^{\text {th }}$ century (e.g. Brard 1808: "Marbre madréporique de Mons (Petit gris, ou Petit Granit des marbriers" [p. 372], or "ce vilain marbre du département de Jemappes connu sous le nom de Petit Granit" [p. 398]).

The stone can be worked and polished in all common styles. It is one of the few calcareous stones that can receive flame treatment. The stone characterizes many façades of the urban architecture of Brussels and other Belgian cities, and since the second half of the 19th century it has been used in various countries in Europe and overseas. Exportation of this natural stone to Germany has led to it being known commercially there by the name of "Belgisch Granit" (Belgian Granite), thereby continuing the misunderstanding regarding its rock type, and also "Belgischer Blaustein" (Belgian blue stone).

Petit Granit has also been used widely in sculpture and architecture by several well known artists (e.g. Mateo Hernández, Michel 


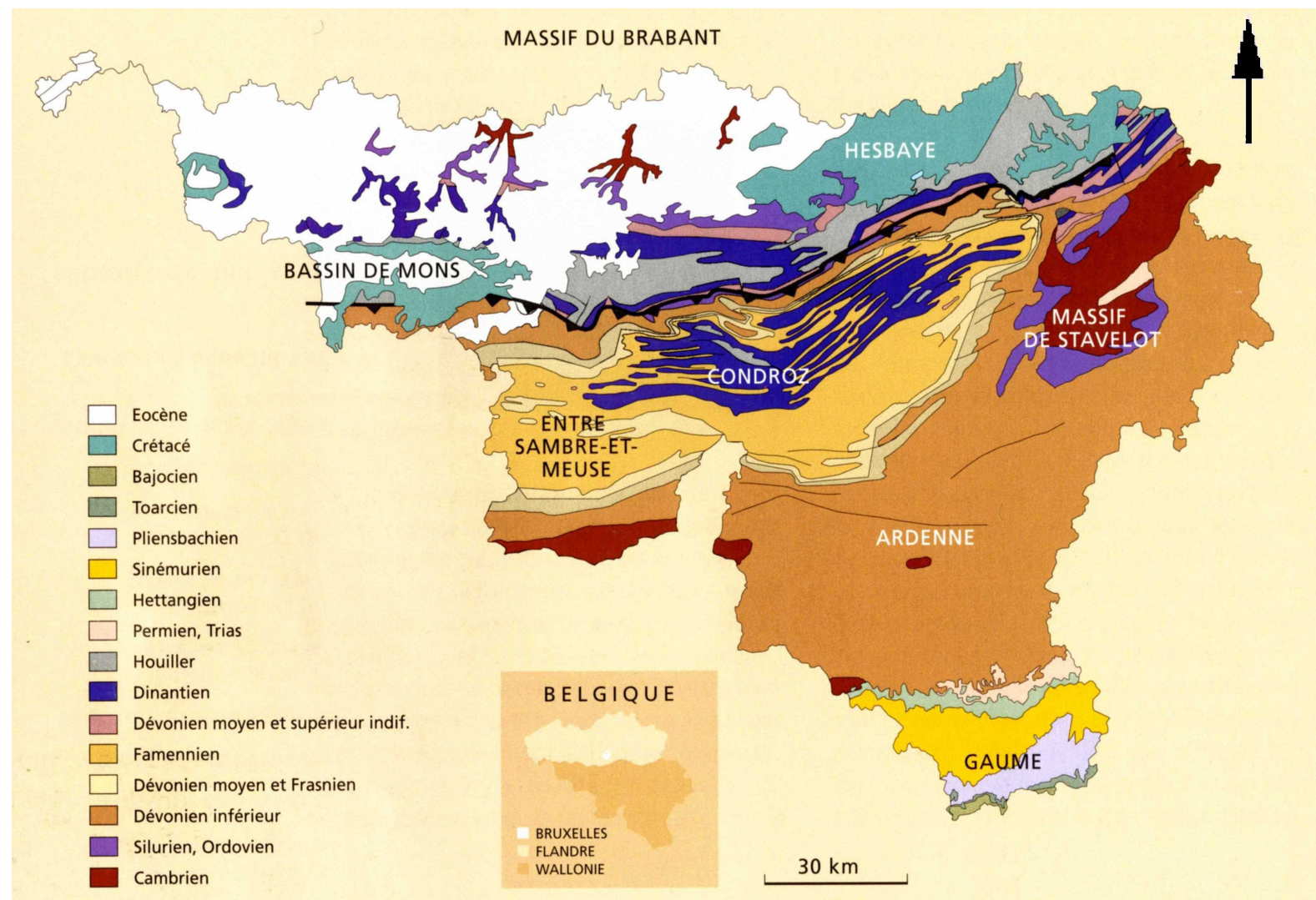

Figure 1. Map of Belgium showing distribution of lithologies. Marchi and Tourneur (2002)

Smolders, Tom Blatt, Belgischer Blaustein, Belgischer Blaustein, Santiago Calatrava, among others).

\section{Petit Granit as Global Heritage Stone Resource}

The essential characteristics of a Global Heritage Stone Resource (GHSR) are now defined (Hughs et al. 2013; Cooper et al. 2013; HSTG "Terms of Reference" approved by IUGS at its Executive

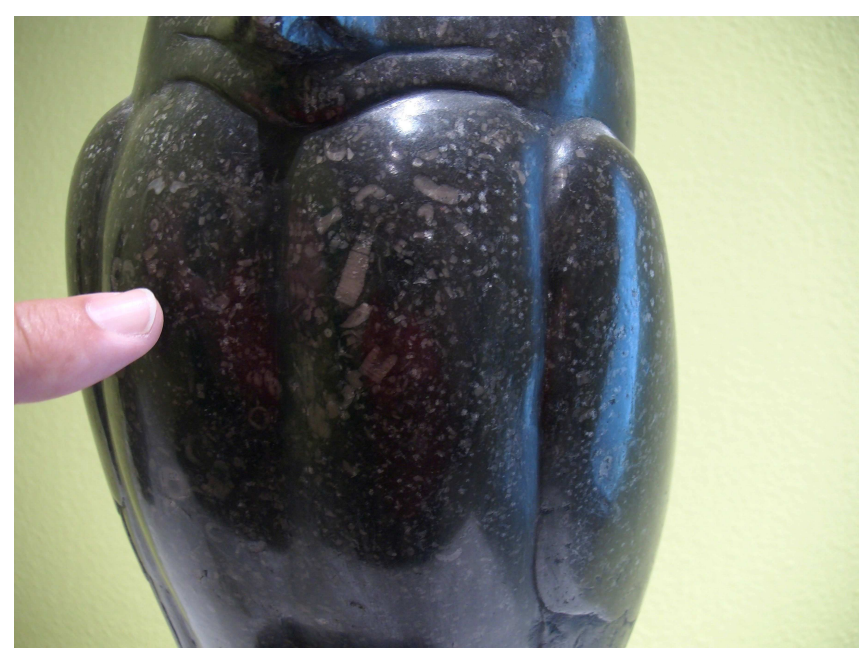

Figure 2. Mateo Hernández's “Owl”, made on Petit Granit where the white fossils against the black background explain the controversial name for a limestone. Reference on the material at the museum: Granito Negro (Black Granite). Photo by D. Pereira.
Committee Meeting in San Sebastian, Spain in February 2012 (http:/ /www.globalheritagestone.org/home/ghsr-proposals). An approved GHSR nominee must have a cultural history encompassing a significant period of time and needs to have been utilised in significant works, either in buildings, sculpture or utilitarian applications. Wide geographical use, extending if possible to numerous countries, is important. In addition, recognition as a cultural icon, potentially including association with a national identity or a significant individual contribution to architecture, is also valuable. In the case of Petit Granit, all these characteristics are accomplished. Contemporary quarrying and therefore the on-going availability of a GHSR for construction can increase the status of a GHSR and hence is also beneficial. As a consequence of this availability, technical investigations are encouraged, and continued use of the GHSR stone is promoted. With contemporary quarrying, GHSR designation may safeguard the resource from future inaccessibility resulting from quarry closure. Such inaccessibility has long been a problem given the common close proximity of dimension stone quarries to other human activities.

\section{Required GHSR Nomination/Citation data}

For the purpose of GHSR nomination, the HSTG Terms of Reference state that citations shall contain specific information (Cooper et al. 2013), as follows.

Formal Name: Petit Granit.

Other Names: Pierre Bleue de Belgique, Blue Stone, Belgian Blue Stone (not to be confused with Chinese Bluestone or Irish Bluestone), Belgian Limestone. 
Place of Origin: Southern Belgium.

Resource Location: Petit Granit is exclusively extracted in Belgium. Four regions are known for having quarries (Figure 1):

- Hainaut province: Soignies and Neufvilles, formerly Écaussinnes, Feluy, Arquennes

- Condroz area: Sprimont, Chanxhe, Anthisnes, Clavier, Modave, Ouffet, Pailhe, Les Avins

- Valley of the Bocq: Dorinne, also in Yvoir and Spontin for the variety Petit Granit du Bocq

- Valley of the Molignée: for the moment, no active exploitation, formerly Denée

Today there are two major production regions:

- Hainaut (approximately $80 \%$ of the total)

- The Ourthe-Amblève region, south of Liège.

Quarrying: Petit Granit has been extracted in several regions of southern Belgium since the Middle Age (Figure 3a and 3b). Around fifteen quarries are active these days, employing almost one thousand people. A map with specific locations of present-day quarries is at http://www.pierresetmarbres.be.

Heritage issues: The quarries are being considered within the European Quarry Landscapes project, which considers historic quarries and landscapes formed by quarrying across Europe (http://www.quarrylandscapes.teruel.es/)

Victor Hugo mentioned the Petit Granit in his travel writings (e.g. "Ces roches de la Meuse contiennent beaucoup de fer; mêlées au paysage, elles sont d'une admirable couleur: la pluie, l'air et le soleil les rouillent splendidement; mais, arrachées de la terre, exploitées et taillées, elles se métamorphosent en cet odieux granit gris bleu dont toute la Belgique est infestée. Ce qui donnait de magnifiques montagnes ne produit plus qued' affreusesmaisons. Dieu a fait le rocher, l'homme a fait le moellon." (Rouvez, 1909)

Petrographic Name: Crinoidal limestone (bioclastic packstone [Dunham, 1962]; biomicrite [Folk, 1959])
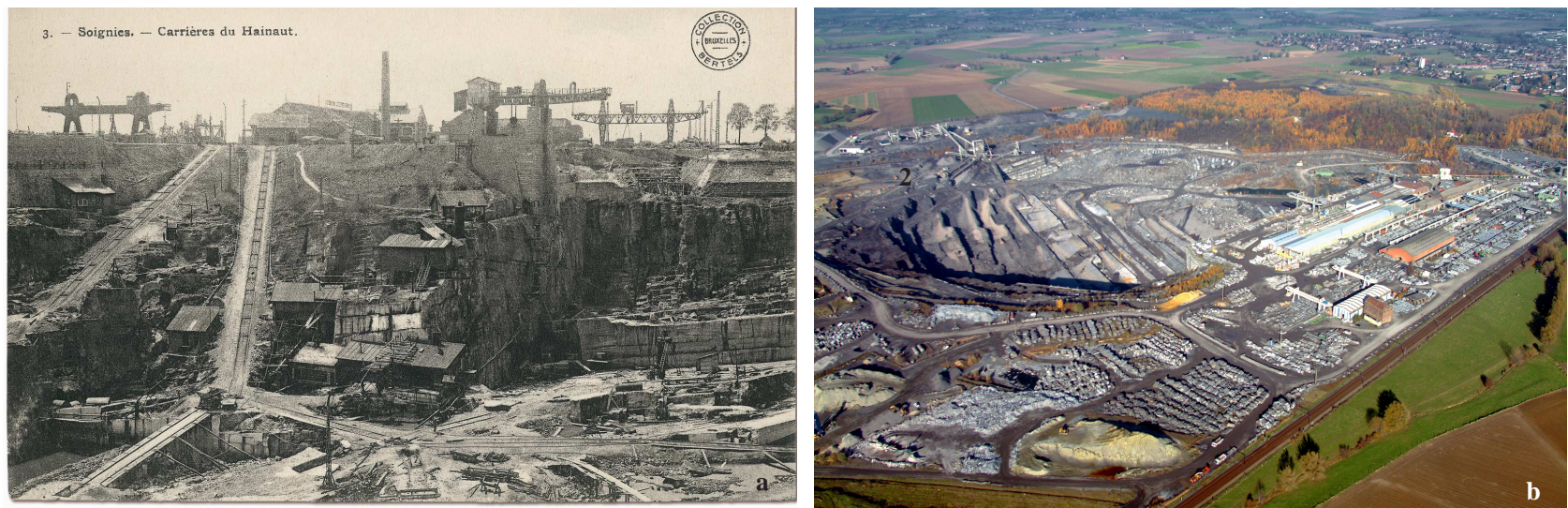

Figure 3 (a) Quarries at Hainaut. Past. At the beginning of XXth century, the landscape looks more "industrial' with many travelling cranes, but with still old installations. Collection Bertels, Brussels. (b). Quarries at Hainaut. Present. The position of strata in Soignies, with a gentle slope of $12-13^{\circ}$, allows exploitation in huge terraces and production of very large blocks of good stone. $99 \%$ carbonate (with a minimum of $88 \%$ calcite), 0 to $1 \%$ quartz, 0,1 to $0,4 \%$ iron (mainly as pyrite) and 0,2 to $0,4 \%$ of organic carbon (which gives the dark colour in fresh surfaces).

Colour: Grey-bluish, dark-grey on freshly broken surface, to lightgrey with a slight bluish shade as a patina.

Natural variability: The strata of Petit Granit are well known for their homogeneity and uniform character. There is a slight variability in the size and density of crinoid ossicles, and also a slight variation of colour, somewhat darker ("bancs noirs") or lighter ("bancs gris"). The many different finishing possibilities for the rock, smooth or rough ones, alter the colour appearance.

Suitability: The Petit Granit is covered by a technical agreement referred to "Agrément technique avec certification", under the authority of the Union belge pour l'agrément technique dans la construction, (http://www.ubatc.be), where all the geological and technical data are given. Its high density and uniformity mean that it takes an excellent polish and thus has versatile use as a dimension stone. It can be used in nearly every kind of applications in architecture, garden and landscape architecture, decoration and sculpture. However, some finishing styles are not long-lasting in external uses and are reserved for inside decoration.

Stratigraphy: Different varieties are found in early Carboniferous strata, from middle to late Tournaisian age. Petit Granit s.s.is of middle Tournaisian age. The limestone was formed in a shallow-marine depositional environment, in tropical conditions, inhabited by many invertebrate organisms, such as crinoids, corals and brachiopods. For a complete geological explanation: http://www2.ulg.ac.be/geolsed/geolwal/ geolwal.htm

Commercial designation: "Pierre Bleue de Belgique ${ }^{\circledR ”}$, a registered name.
Mineralogical composition: The mean composition is of 96 to 
Physical properties:

Extracted from http://www.pierrebleuebelge.be/images/biblio/ biblio-74-710.pdf

Water absorption $(\%)$

0.11

Mean Density $\left(\mathrm{kg} / \mathrm{m}^{3}\right)$

2687

Mean Porosity (\%)

0.28

Mean Compressive Strength (MPa) $\quad 157.90$

Mean Flexural Strength (MPa) $\quad 16.70$

Wear resistance $(\mathrm{mm}) \quad 18.80$

Static Elastic module (GPa) $\quad 86.90$

Dynamic Elastic module (GPa) $\quad 86.90$

Vulnerability and maintenance of supply: Petit Granit is only quarried in Belgium.

Production figures for 2006 were $38.000 \mathrm{~m}^{3}$ at Clypot site and $17.000 \mathrm{~m}^{3}$ at Gauthier and Wincqz site (extracted from: http:/ /www.pierrebleuebelge.be/key-figures.45-uk.html)

The annual turnover for all Petit Granit quarries in Belgium is $65,000,000$ euros at present, including $30 \%$ of exports. The quarries employ 650 people (400 only at 'carrières du Hainaut'). This data guarantee the maintenance of extraction activity for the future.

Historic Use: Petit Granit has an Appellation d'Origine Locale (Local Appellation of Origin) designation since 1999. It has been extracted in several regions of southern Belgium since the Middle Ages. Architects and sculptors have been using this stone since at least the $12^{\text {th }}$ century.

\section{Buildings}

Historical (with date of construction in brackets):

- Cathedral of Funchal, Madeira $\left(15^{\text {th }} \mathrm{c}\right.$. $)$

- Collegiate church of Sainte-Waudru, Mons, Belgium (interlaid with sandstone) $\left(15^{\text {th }}-16^{\text {th }} \mathrm{c}\right.$.)

- Other churches and private houses in Mons and region, Belgium $\left(15^{\text {th }}-19^{\text {th }} \mathrm{c}.\right)$

- Garden pavilion, parc d'Arenberg, Enghien, Belgium (17 ${ }^{\text {th }} \mathrm{c}$.)

- Castle of Seneffe, Belgium, by the architect L.B. Dewez (mid-18 $18^{\text {th }} \mathrm{c}$ )

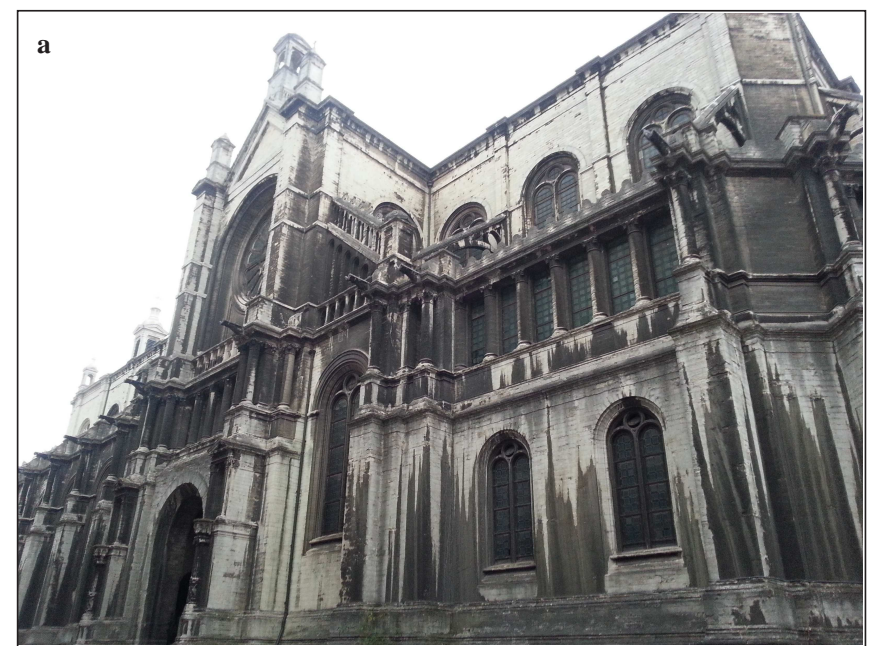

- Flooring, Panthéon, Paris, interlaid with French stones, by architect Rondelet (beginning of $19^{\text {th }} \mathrm{c}$.)

- Galeries Royales Saint-Hubert, by architect Jean-Pierre Cluysenaer, Brussels, Belgium (1846-1847)

- Palais du Gouverneur (neogothic), Liège, Belgium (1850)

- Saint Catherine's church (Figure 4a), central Brussels, Belgium, designed by Joseph Poelaert (1854)

- Palais du Cinquantenaire (Figure 4b) Brussels, Belgium (1880)

- Palais du Centenaire, Brussels, Belgium (1930)

- Maison du Roi (Grand-Place), neogothic restoration, Brussels, Belgium (1890)

- Many Art Nouveau private houses, including that of Victor Horta (UNESCO). Brussels, Belgium (1892-93)

- Pont de Fragnée, Liège, Belgium (for Universal Exhibition of 1905)

- Entrance of Canal Albert, Liège, Belgium (International Exhibition of 1930)

- Art Deco town hall, Charleroi, Belgium, by the architects J. Cézar \& J. André (1936) (interlaid with French limestone)

\section{Recent buildings}

- 'Amphithéâtre de l'Europe' at the University of Liège (Sart-Tilman) (Figure 5)

- Brussels airport, Belgium

- Leipzig airport, Germany

- Belgium embassy in Berlin, Germany

- Belgium embassy in Tokyo, Japan

- Chartres town centre, France

- Design centre, Saint-Etienne, France

- Factories Leblan Lafont, Lille, France

- Granite Tower, Paris, France

- Place d'Armes, Valenciennes, France

- Liège-Guillemins railway station, Belgium (Figure 6)

- Maastricht station, Netherlands

- The Hague station, Netherlands

- The Hague town hall, Netherlands

And many newer commercial buildings (e.g. Figure 7)

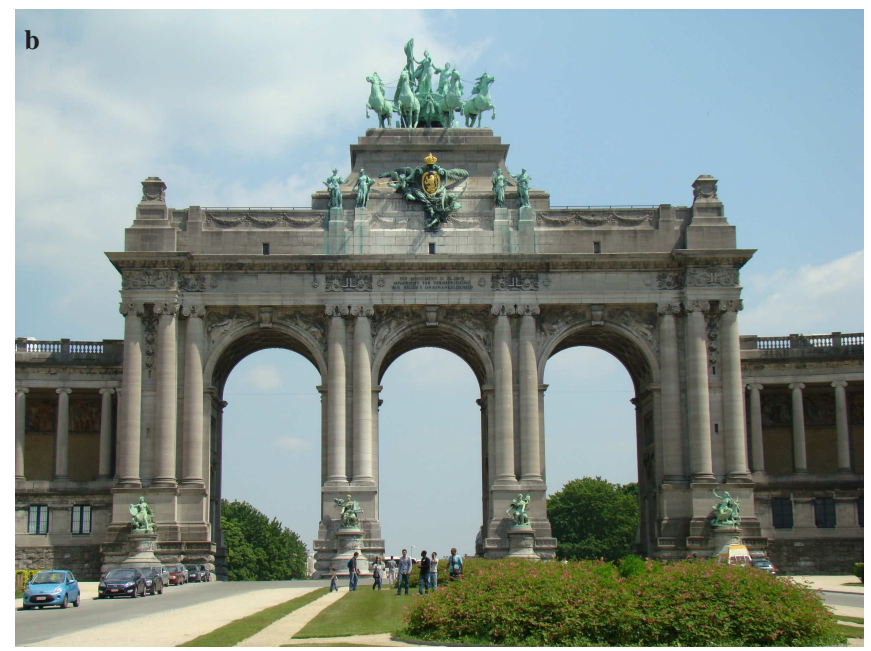

Figure 4. (a) Sainte-Catherine church, Brussels. 1854-1874 by architects Joseph Poelaert and Wynand Janssens. (b) Palais du 'Cinquantenaire' in Brussels and its 'Arc de Triomphe', architect Charles Girault, 1905. 

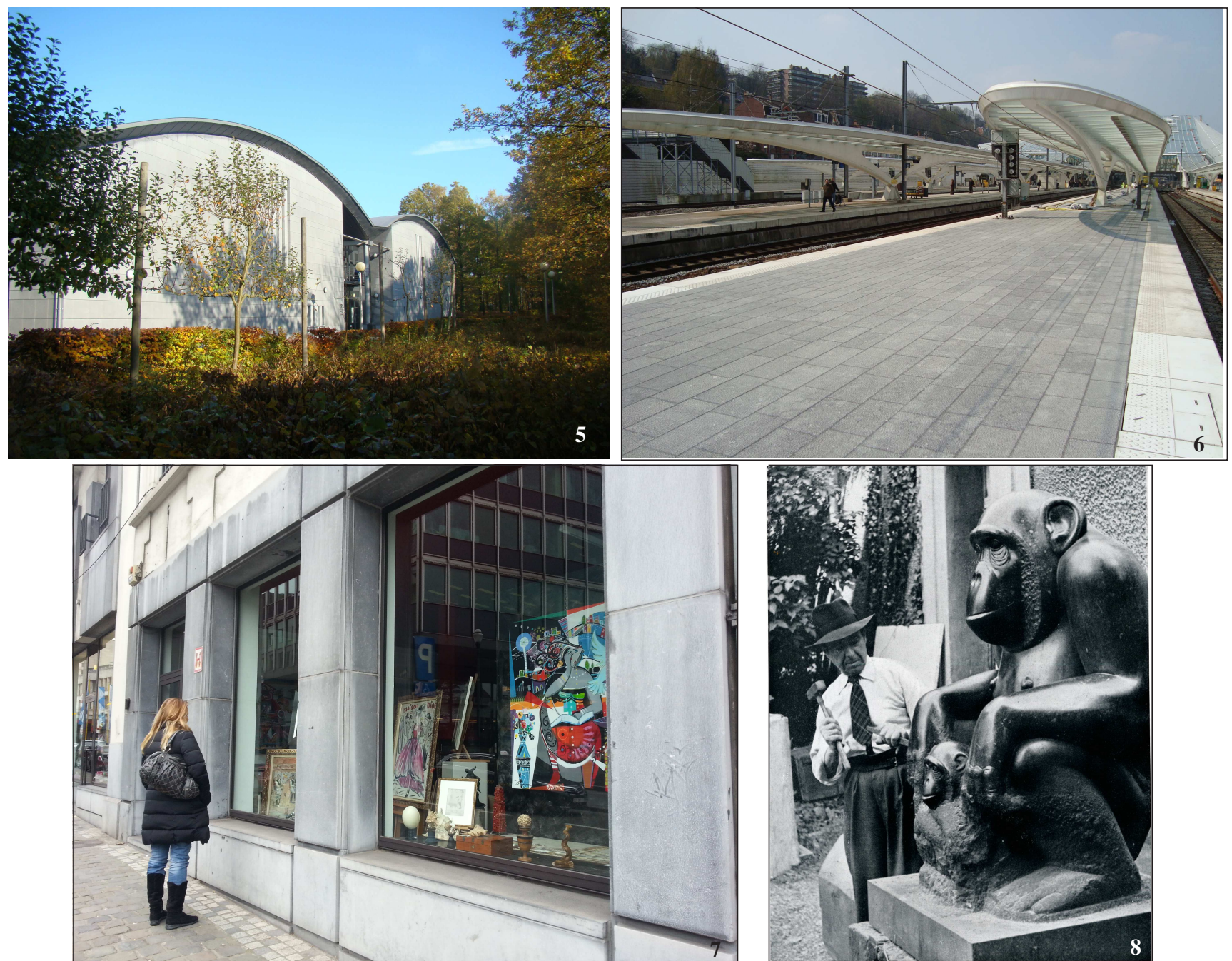

Figures 5-8. (5) 'Amphithéâtre de l'Europe’ at the University of Liège (Sart-Tilman), architect Daniel Dethier, 1996. (6) 'Gare (Station) des Guillemins' at Liège, architect Santiago Calatrava, 2009. (7) Petit Granit in façade of commercial building in central Brussels. (8) Mateo Hernández (Hernández, 1954). In the original: “Groupe de Chimpanzés, en granit noir”. Notice the misnomer in giving the nature of the stone.

Sculptures: Petit Granit has also been used widely in sculpture and architecture by a number of well-known artists. The list is long, but included is a selection of some sculptors, starting with Mateo Hernández (Figure 8), whose works appear in a dedicated museum in Béjar, Salamanca (Spain).

- Mateo Hernandez (Hernández, 1950; Bernáldez Villarroel and Brasas Egido,1998; BernáldezVillarroel, 2000)

- Käthe Kollwitz

- Michel Smolders

- Elise Delbrassinne

- Benoît Luyckx

- Eugène Dodeigne

- Florence Freson

- Félix Roulin

- Philippe Ongena

- Tom Blatt

- Santiago Calatrava

Other characteristics: Because the depositional environment was one of high water-column productivity which led to mostly reducing conditions in the sediment, sulphide minerals (pyrite) were created and the limestone contains a high percentage of organic carbon. For this reason it is also called "coal lime". One characteristic of this rock is the smell it produces when broken or scratched due to the hydrogen sulphide released, which explains the nickname "stink lime".

\section{Conclusion}

Petit Granit fulfils all the requirements to be presented as candidate for designation as a GHSR, both for construction and artistic purposes, but especially for its widespread use as a dimension stone for building exteriors.

\section{Acknowledgements}

This work was sponsored by the ERASMUS Intensive Programme 2012-1-ES1-ERA10-54375 and it was done within the framework of Heritage Stone Task Group activities. University of Salamanca funding program supports this publication. Brian Pratt is acknowledged for his review and useful comments on the paper. The city council of Béjar is acknowledged for the support received in visiting Mateo Hernández museum. 


\section{References}

Bernáldez Villarroel, L. 2000. La piedra y la palabra. Mateo Hernández en las hemerotecas (1905-1999). Ed. Caja Duero, 680 p. (In Spanish)

Bernaldez Villarroel, L. and Brasas Egido, J.C. 1998. Mateo Hernández 1884-1949, un escultor español en Paris. Junta de Castilla y Leon, 343 p. (In Spanish)

Brard, C.P. 1808. Traité des pierres précieuses, des porphyres, granits, marbres, albâtres et autres roches, $2^{\text {nd }}$ partie. F. Schoell, Paris, 565 p. (In French)

Cooper, B.J., Marker, B.R., Pereira, D. and Schouenborg, B. 2013. Establishment of the "Heritage Stone Task Group" (HSTG). Episodes, v. 31, pp. 8-10.

Dunham, R.J. 1962. "Classification of carbonate rocks according to depositional texture". In Ham, W.E. Classification of carbonate rocks. American Association of Petroleum Geologists Memoir. 1, pp. 108-121.

Folk, R.L., 1959. Practical petrographic classification of limestones: American Association of Petroleum Geologists Bulletin, v. 43, pp. 1-38.

Groessens, E. 2013. Le Petit-Granit, les prémices d'une grande histoire industrielle, in Toussaint, J. (ed.): Actes du colloqueautour des marbresjaspés. Monographies du Musée des Arts anciens du Namurois, 59, Namur, pp. 222-245. (In French)

Groessens, E. and Tourneur, F. 2011. Les "pierresbleues", fleurons incontestés de l'industrie extractive wallonne, une industrie toujours bien vivante! In: Toussaint, J. (ed.) Regards sur le bleu, Monographies du Musée des Arts anciens du Namurois, 51, Namur, pp. 48-63. (In French)

Hernández, F. 1950. M. Hernández. SculpteurEspagnol (18851949)". Bella Vista. Meudon. (In French)

Hughes, T., Lott, G.K. Poultney, M.J. \& Cooper, B.J. 2013. Portland Stone: A nomination for "Global Heritage Stone Resource" from

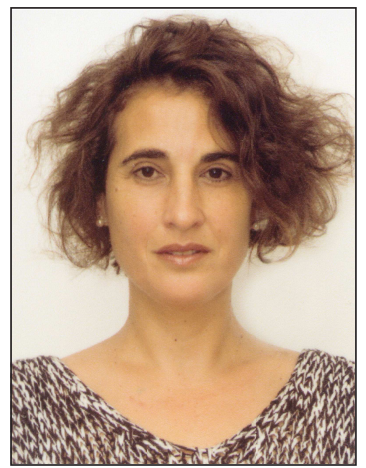

Dolores Pereira is professor at Geology and Engineering Geology degrees at the University of Salamanca. She is vicepresident of the IUGS Heritage Stone Task Group for southern Europe and Member of the network CONSTRUROCK. She is adviser and reviewer for UNESCO on World Heritage Sites. Her research interests include natural stones and their use in new building and restoration of architectonic heritage.

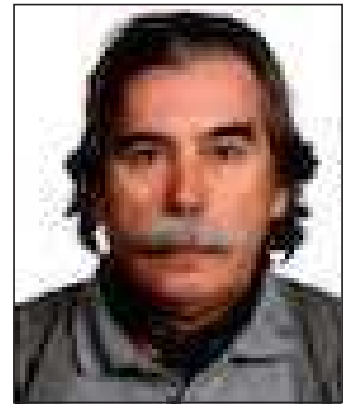

Lorenzo Bernáldez Villaroel. He studied Fine Arts at the University of Sevilla and is Doctor in Fine Arts by the University of Salamanca. Author of several scientific publications and outreach activities on the sculptor Mateo Hernandez, right now is the director of the Integrated Municipal Centre "Julian Sánchez, el charro" in Salamanca. the United Kingdom. Episodes 36: 221-226.

Marchi, C. and Tourneur, F. 2002. Living Stones. Ornamental stones in Belgium: a general-Sprimont (Pierres et Marbres de Wallonie), p. 134.

Tourneur, F. 2004. Marbres wallons: esquisse d'un répertoire. In: Carpeaux, C., Marchi, C., Merland, M. and Tourneur, F. (ed.): Pouvoirs(s) de marbres, Dossiers de la Commission royale des Monuments, Sites et Fouilles, 11, Liège, 32 p. (In French)

Rouvez, A. Th. 1909. Cités et villes belges. Librairie nationale d'Art et d'Histoire. G. van Oest and Cie., Brussels, 147 p. Available on line: http://passerellesdutemps.free.fr/edition_numerique/IGCD/ 9_GEOGRAPHIE_\%20HISTOIRE_SCIENCES_AUXILIAIRES_DE_L_ HISTOIRE/91_Geographie_explorations_voyages/914.493_ Cites_et_villes_belges.pdf. (In French)

\section{Websites}

http://en.wikipedia.org/wiki/K\%C3\%A4the_Kollwitz(last accessed 1 September 2014).

http://www.jeanbrolly.com/artiste/eugene-dodeigne/ (last accessed 1 September 2014).

http://www2.ulg.ac.be/geolsed/geolwal/geolwal.htm (last accessed 1 September 2014).

http://www.federationpierrebleue.be/ (last accessed 1 September 2014).

http://www.tomblatt.blogspot.com.es/(last accessed 1 September 2014).

http://www.almut-im-inter.net/steine/stein2/2_bgranit.htm (last accessed 1 September 2014).

http://whc.unesco.org/ (last accessed 1 September 2014).

http://www.benoit-luyckx.com/ (last accessed 1 September 2014). http://www.felixroulin.be/ (last accessed 1 September 2014).

http://www.fontaines-pierre-ongena.be/ (last accessed 1 September 2014).

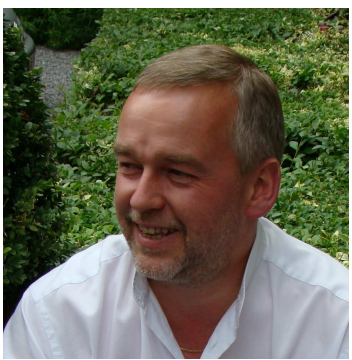

Francis Tourneur. Doctor in Sciences, first paleontologist, then specialist of building materials, general secretary of the association 'Pierres et Marbres de Wallonie', teaching at the University of Liège (Faculté d'Architecture) and at the KULeuven (Centre Lemaire).

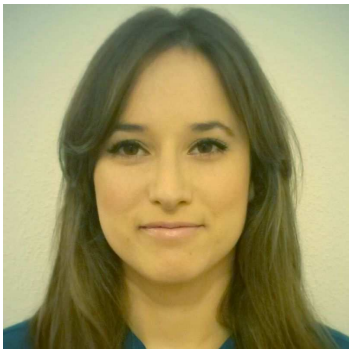

Ana García Blázquez. Student of Engineering Geology in her last year. Her final year project is related to the Petit Granit, together with other natural stones used by the sculptor Mateo Hernández. She was student in practice for the Spanish Geological Survey during the first stage of the final project. 